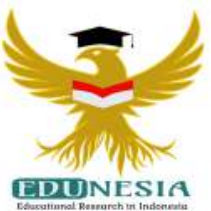

\title{
Pengembangan Bahan Ajar Berbasis Masalah Terintegrasi Etnomatematika Untuk Meningkatkan Kemampuan Pemecahan Masalah Siswa Kelas XI SMA
}

\author{
Ana Wiska1; Henra Saputra Tanjung2; Arief Aulia Rahman ${ }^{3}$; Cut Eva Nasryah ${ }^{4}$ \\ 1,2,3Pendidikan Matematika, STKIP Bina Bangsa Meulaboh, Indonesia \\ ${ }^{4}$ Pendidikan Guru Sekolah Dasar, STKIP Bina Bangsa Meulaboh, Indonesia \\ ${ }^{1}$ Corresponding Email: anawiska04@gmail.com, Phone Number : 0821 xxxx xxxx
}

Article History:

Received: July 07, 2020

Revised: Sept 10, 2020

Accepted: Okt 15, 2020

Published: Nov 01, 2020

\section{Keywords:}

Etnomathematics,

Teaching Material,

Problem Solving.

Kata Kunci:

Bahan ajar,

Etnomatematika,

Pemecahan masalah.

\section{How to cite:}

Wiska, A., Tanjung, H.S, Rahman, A.A., \& Nasryah, C.E. (2020). Pengembangan Bahan Ajar Berbasis Masalah Terintegrasi Etnomatematika Untuk Meningkatkan Kemampuan Pemecahan Masalah Siswa Kelas XI SMA. Edunesia : Jurnal Ilmiah Pendidikan, 1 (3): 9-20

This is an open access article under the $C C-B Y-N C-N D$ license

\begin{abstract}
It takes teaching material that can train students in solving mathematical problems. One of the teaching materials that can be developed to improve students' mathematical problem solving skills is problem-based teaching material. The purpose of this research is to describe: the validity of integrated problem-based ethnomatematics teaching materials developed; the effectiveness of ethnomatematics integrated problem-based teaching materials developed; and student responses to integrated problem-based ethnomatematics teaching materials developed. This research is a research development. This research was conducted through two stages, namely the first stage of developing ethnomatematics integrated problem-based teaching materials using the Four-D model, and the second stage of testing the ethnomatematics integrated problem-based teaching materials developed in class XI of SMA Negeri 1 Meureubo to see their effectiveness. From these two stages, it was obtained: integrated ethnomatemics problem-based teaching materials developed were valid, based on the results of the validation conducted by the validators; integrated ethnomatematics problem-based teaching materials developed effectively, in terms of classical student mastery learning and achievement of learning objectives; and positive student responses to the integrated problem-based ethnomatematics activity and teaching material developed.
\end{abstract}

Abstrak: Dibutuhkan bahan ajar yang dapat melatih siswa dalam memecahkan masalah matematika. Salah satu bahan ajar yang dapat dikembangkan untuk meningkatkan kemampuan pemecahan masalah matematika siswa adalah bahan ajar berbasis masalah. Tujuan penelitian ini adalah untuk mendeskripsikan: kevalidan bahan ajar berbasis masalah terintegrasi etnomatematika yang dikembangkan; efektifitas bahan ajar berbasis masalah terintegrasi etnomatematika yang dikembangkan; dan respon siswa terhadap bahan ajar berbasis masalah terintegrasi etnomatematika yang dikembangkan. Penelitian ini merupakan penelitian pengembangan. Penelitian ini dilakukan melalui dua tahap, yaitu tahap pertama mengembangkan bahan ajar berbasis masalah terintegrasi etnomatematika menggunakan model pengembangan Four-D, dan tahap kedua mengujicobakan bahan ajar berbasis masalah terintegrasi etnomatematika yang dikembangkan di kelas XI SMA Negeri 1 Meureubo untuk melihat efektifitasnya. Dari kedua tahap tersebut, diperoleh: bahan ajar berbasis masalah terintegrasi etnomatematika yang dikembangkan valid, berdasarkan hasil validasi yang dilakukan oleh para validator; bahan ajar berbasis masalah terintegrasi etnomatematika yang dikembangkan efektif, ditinjau dari ketuntasan belajar siswa secara klasikal serta ketercapaian tujuan pembelajaran; dan respon positif siswa terhadap aktifitas dan bahan ajar berbasis masalah terintegrasi etnomatematika yang dikembangkan. 


\section{A. Pendahuluan}

Pendidikan merupakan suatu proses yang dilalui oleh seseorang agar memperoleh pengalaman belajar dan mengembangkan seluruh potensi yang dimiliki. Pendidikan dapat dilaksanakan dalam lembaga yang bersifat formal maupun non-formal. Pada pendidikan formal penyelenggara pendidikan tidak terlepas dari tujuan pendidikan yang akan dicapai, karena tercapai atau tidaknya tujuan pendidikan merupakan tolak ukur dari keberhasilan penyelenggaraan pendidikan (Kharisma dan Asman, 2018). Oleh sebab itu, sekolah yang merupakan salah satu lembaga pendidikan formal memiliki tujuan pendidikan yang dioperasionalkan menjadi tujuan pembelajaran dari bidang studi tertentu termasuk matematika.

Dalam konteks pendidikan, salah satu hal yang sangat perlu untuk diperhatikan adalah mutu pendidikan. Tinggi rendahnya mutu pendidikan suatu negara sangat berpengaruh terhadap perkembangan dan kemajuan negara tersebut (Ulfa \& Nasryah, 2020). Indonesia merupakan salah satu negara yang mutu pendidikannya masih dikatakan rendah. Rendahnya mutu pendidikan khusunya matematika, membuat Indonesia masih jauh tertinggal dengan negara-negara lain. Berdasarkan hasil survei dari Program For Internasional Assessment of Students (PISA) pada tahun 2015 menunjukkan kemampuan matematika siswa Indonesia menempati peringkat 63 dari 70 negara. Sementara itu, IEA menyatakan hasil dari studi Trends in International Mathematics and Science Study (TIMSS) tahun 2015 menunjukkan prestasi matematika siswa Indonesia berada pada peringkat 44 dari 49 negara (Nurliastuti, dkk, 2018).

Dari hasil survei dan studi di atas, menunjukkan betapa rendahnya kemampuan matematika siswa di Indonesia, padahal matematika merupakan ilmu universal yang mendasari perkembangan teknologi modern dan mempunyai peran penting dalam memajukan pola pikir manusia. Selain itu matematika juga merupakan ilmu dasar yang memiliki pengaruh terhadap perkembangan ilmu-ilmu lain seperti ilmu kedokteran, ilmu fisika, ilmu sosial dan ilmu alam.

Pembelajaran matematika merupakan pembelajaran yang tidak hanya menekankan pada kemampuan berhitung saja, akan tetapi ada beberapa aspek lain yang menjadi tujuan dari pembelajaran matematika. Adapun tujuan dari pembelajaran matematika di sekolah menurut Permendiknas Nomor 22 Tahun 2006 adalah sebagai berikut : (1) Memahami konsep matematika, menjelaskan keterkaitan antara konsep dan mengaplikasikan konsep atau algoritma secara luwes, akurat, efesien dan tepat dalam pemecahn masalah; (2) Menggunakan penalaran pada pola dan sifat, melakukan manipulasi matematika dalam membuat generalisasi, menyusun bukti, atau menjelaskan gagasan dan pernyataan matematika; (3) Pemecahan yang meliputi kemampuan memahami masalah, merancang model matematika, menyelesaikan model dan menafsirkan solusi yang diperoleh; (4) Mengkomunikasikan gagasan dengan symbol, tabel, diagram, atau media lain untuk menjelaskan keadaan atau masalah; (5) Menghargai kegunaan matematika dalam kehidupan, yaitu rasa ingin tahu, perhatian, dan minat dalam mempelajari matematika, serta sikap ulet dan percaya diri dalam penyelesaian masalah; dan (6) Menalar secara logis dan kritis serta mengembangkan aktivitas kreatif dalam memecahkan masalah dan mengkomunikasikan ide. Disamping itu, memberi kemampuan untuk menerapkan matematika pada setiap pogram keahlian.

Berdasarkan tujuan pembelajaran matematika di atas, maka dapat disimpulkan bahwa dalam pembelajaran matematika bukan hanya pemahaman konsep yang menjadi tujuannya, akan tetapi juga ada beberapa tujuan lain salah satunya ialah pemecahan 
masalah. Menurut Rahman (2018), pemecahan masalah matematika merupakan hal yang sangat penting karena dengan berusaha mencari pemecahan masalah secara mandiri akan memberikan suatu pengalaman yang konkrit sehingga dengan pengalaman tersebut dapat digunakan dalam memecahkan masalah-masalah serupa.

Menurut Tanjung (2018), kemampuan pemecahan masalah matematis siswa dapat dilihat dari alur siswa dalam menyelesaikan masalah. Langkah-langkah yang perlu dilakukan dalam pemecahan masalah ini adalah: (1) Memahami masalah, yaitu siswa mampu menuliskan apa yang diketahui dan ditanyakan soal, apakah data yang diperlukan cukup atau berlebih; (2) Merencanakan penyelesaian, yaitu siswa mampu menuliskan algoritma yang akan ditempuh untuk menyelesaikan soal, konsep-konsep matematika apa yang diperlukan untuk menyelesaikan soal tersebut; (3) Melaksanakan perencanaan penyelesaian masalah, yaitu siswa menyelesaikan soal sesuai dengan algoritma yang direncanakan; (4) Memeriksa kembali hasil, apakah hasil yang diperoleh sudah benar atau belum, jika belum maka siswa perlu mengecek ulang algoritma penyelesaiannya.

Hasil observasi yang peneliti lakukan di SMA Negeri 1 Meureubo menunjukkan bahwa kemampuan pemecahan masalah siswa pada umumnya masih rendah. Berikut ini adalah hasil tes dari salah satu siswa SMA Negeri 1 Meureubo yang dilakukan oleh peneliti.

Hasil observasi yang peneliti lakukan di SMA Negeri 1 Meureubo menunjukkan bahwa kemampuan pemecahan masalah siswa pada umumnya masih rendah. Berikut ini adalah hasil tes dari salah satu siswa SMA Negeri 1 Meureubo yang dilakukan oleh peneliti.

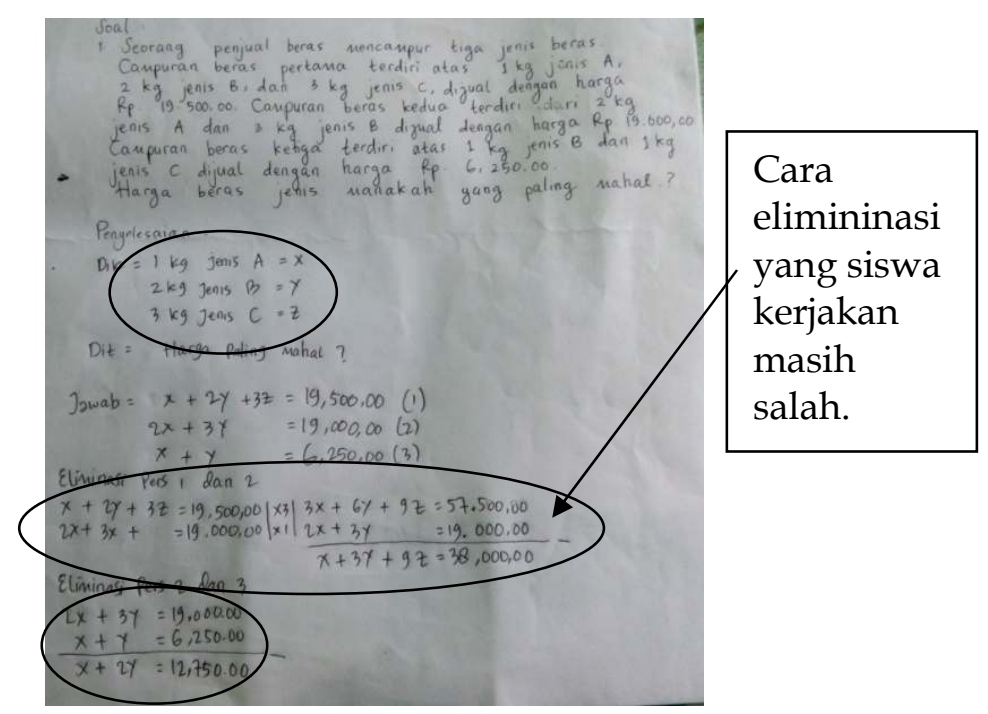

Gambar 1. Hasil Tes Salah Satu Siswa

Siswa masih belum bisa memahami masalah pada soal, siswa masih belum bisa dalam mengidentifikasi informasi dari masalah dengan baik dan siswa masih keliru dalam mengerjakan proses penyelesaian terkait metode eliminasi. Setelah tes dilakukan, kemudian peneliti melanjutkan dengan melakukan diskusi dengan siswa. Dari hasil diskusi tersebut memberikan informasi, bahwa siswa kesulitan di dalam mengerjakan soal karena mareka kurang paham dalam memahami masalah yang ada. Hal ini menunjukkan bahwa kemampuan pemecahan masalah siswa masih kurang, sehingga siswa mengalami kesulitan-kesulitan di atas. 
Selain tes pemecahan masalah yang telah dipaparkan di atas, peneliti juga melakukan observasi mengenai bahan ajar yang digunakan guru dalam pembelajaran. Hasil observasi tersebut menunjukkan bahwa bahan ajar yang digunakan adalah buku ajar kurikulum 2013, walaupun terkadang juga masih menggunakan buku ajar KTSP sebagai referensi lain (Aristia, dkk, 2020). Selanjutnya peneliti melakukan diskusi dengan guru bidang studi yang bersangkutan. Hasil diskusi tersebut memberikan informasi kepada peneliti bahwasanya proses pembelajaran yang dilakukan selama ini ialah pembelajaran yang masih berpusat pada guru. Hal ini dilakukan guru karena mengingat kebanyakan siswa kurang tertarik belajar matematika, dan tidak mengerti jika proses pembelajaran dilakukan secara mandiri, sehingga proses pembelajaran secara aktif sedikit susah untuk diterapkan.

Berdasarkan fakta yang telah dipaparkan di atas, maka perlu adanya perhatian untuk bisa mengembangkan dan meningkatkan kemampuan pemecahan masalah siswa. Dalam upaya mengembangkan dan meningkatkan kemampuan pemecahan masalah siswa, tentunya banyak kendala yang harus dihadapi, salah satunya adalah bahan ajar. Beberapa penelitian sebelumnya menyebutkan bahwa bahan ajar yang digunakan di sekolah belum memfasilitasi kemampuan siswa, salah satunya penelitian yang dilakukan oleh Mulin (dalam Kharisma dan Asman, 2018), ia mengatakan bahwa bahan ajar selama ini yang digunakan hanya berupa desain sebagai buku teks yang berisi tentang definisi, teorema, pembuktian, contoh soal, dan latihan soal. Oleh karena itu, perlu dikembangkan bahan ajar matematika yang dapat memfasilitasi kemampuan pemecahan masalah matematis siswa.

Bahan ajar adalah seperangkat materi yang disusun secara sistematis sehingga tercipta lingkungan suasana yang memungkinkan siswa untuk belajar. Dengan bahan ajar, maka siswa dapat mempelajari suatu kompetensi secara runtut dan sistematis bahkan secara mandiri (Depdiknas dalam Nurhidayati dkk, 2017).

Menurut LTSN, salah satu bentuk bahan ajar yang dapat dikembangkan untuk memfasilitasi kemampuan pemecahan masalah adalah bahan ajar berbasis masalah. Bahan ajar berbasis masalah marupakan satu bentuk bahan ajar yang mengedepankan permasalahan (problem) sebagai konteks dan daya penggerak bagi siswa untuk belajar. Dengan bahan ajar berbasis Masalah siswa dapat membentuk pemahaman mendalam pada setiap pelajaran, dan meningkatkan keterampilan dalam aspek kognitif, problem solving, kerjasama kelompok, komunikasi dan berfikir kritis (Kurniawati dan Amarlita, 2013).

Selanjutnya dalam rangka mewujudkan pendidikan karakter dan menumbuhkan suasana yang dekat dengan kehidupan siswa, maka peneliti ingin melibatkan budaya lokal siswa yaitu budaya Aceh dalam permasalahan pada bahan ajar yang akan dikembangkan. Pelibatan budaya ini dimaksudkan dapat menjadi daya tarik siswa untuk belajar matematika, karena tak sedikit dari mereka kurang tertarik untuk belajar matematika dan merasa bahwa permasalahan matematika yang ada di buku selama ini, jauh dari kehidupan lokal siswa. Dengan hal ini, diharapan jika siswa telah tertarik untuk belajar, maka kegiatan belajar secara aktif akan bisa dilaksanakan.

Selain itu, di era globalisasi pada abad 21 ini yang disebutnya sebagai zaman melenial, banyak sekali nilai-niai serta unsur budaya yang mulai dilupakan dan mengalami pergeseran. Hal ini didukung oleh pernyataan dari Setyaningrum (2018) yang menyatakan bahwa "globalisasi tanpa disadari telah membawa perubahan yang berdampak pada terjadinya perubahan nilai budaya dan sikap pandangan yang telah berubah terhadap nilai-nilai budaya". 
Nurliastuti, dkk (2018) menyatakan bahwa, dalam menumbuhkan dan mengembangkan nilai luhur bangsa, diperlukan adanya pendekatan pembelajaran yang mengaitkan atau mengintegrasikan budaya lokal dalam pembelajaran matematika yang kemudian disebut dengan etnomatematika. Dengan etnomatematika siswa akan lebih memahami bagaimana budaya mereka terkait dengan matematika, dan para pendidik dapat menanamkan nilai-nilai luhur budaya bangsa yang berdampak pada pendidikan karakter. Oleh sebab itu, maka dengan adanya pengintegrasian etnomatematika diharapkan dapat menjadi daya tarik siswa dalam pembelajaran matematika, serta dapat menanamkan nilai-nilai budaya agar tetap tertanam dan terjaga pada diri siswa selaku penerus bangsa dan budaya di zaman milenial ini.

\section{B. Metode}

Jenis peneliitian yang akan dilakukan adalah penelitian pengembangan. Penelitian ini akan menggunakan model pengembangan 4-D Thiagarajan dan peneliti akan mengembangkan bahan ajar berupa berbais masalah terintegrasi etnomatematika pada materi program linear. Dalam penelitian ini, bahan ajar yang dikembangkan ialah bahan ajar berupa modul matematika. Disamping itu, peneliti juga mengembangkan instrument penelitian yang terdiri dari tes kemampuan pemecahan masalah.

Subjek dalam penelitian ini adalah siswa kelas XI SMA Negeri 1 Meureubo tahun ajar 2019/2020, sedangkan objek dalam penelitian ini adalah bahan ajar berbasis masalah terintegrasi etnomatematika materi program linear yang dikembangkan.

Penelitian ini dibagi menjadi dua tahap, tahap pertama adalah pengembangan bahan ajar. Sedangkan tahap kedua adalah implementasi bahan ajar yang dianggap sudah layak berdasarkan hasil uji coba.

Model pengembangan bahan ajar yang akan dilakukan adalah Model thiagarajan, Semmel, dan Semmel yaitu Model 4-D yang terdiri dari empat tahap yaitu: tahap define (pendefenisian), design (perancangan), develop (pengembangan) dan disseminate (penyebaran). Teknik analisis data yang digunakan dalam penelitian ini adalah :

1. Analisis data validitas bahan ajar.

2. Analisis data efektifitas bahan ajar.

3. Analisis data respon siswa.

\section{Hasil dan Pembahasan}

\section{Deskripsi Kevalidan Bahan Ajar}

Berikut data untuk mengetahui kevalidan bahan ajar yang diperoleh dari penilaian validator teradap bahan ajar program linear berbasis masalah terintegrasi etnomatematika untuk meningkatkan kemampuan pemecahan masalah matematis siswa, seperti yang ditunjukkan pada tabel berikut:

Tabel 1.

Hasil Validasi Bahan Ajar

\begin{tabular}{ccccc}
\hline No & Aspek & $\begin{array}{c}\text { Rata- } \\
\text { rata }\end{array}$ & $\begin{array}{c}\text { Skor } \\
\text { Rata-rata } \\
\text { Keseluruhan }\end{array}$ & Kriteria \\
\hline 1 & Format & 3,33 & 3,22 & Valid \\
\cline { 1 - 3 } 2 & Isi & 3,13 & & \\
\hline
\end{tabular}




\begin{tabular}{ccccc}
\hline & & \multicolumn{2}{c}{$\begin{array}{c}\text { Skor } \\
\text { Rata- } \\
\text { Rata-rata }\end{array}$} & \\
No & Aspek & rata & Keseluruhan & Kriteria \\
\hline 3 & Bahasa & 3,22 & & \\
\hline
\end{tabular}

Berdasarkan data tersebut diperoleh skor rata-rata keseluruhan adalah 3,22 dengan kriteria valid.

\section{Deskripsi Efektifitas Bahan Ajar}

Efektifitas bahan ajar dilihat dari dua aspek, yaitu (a) ketuntasan belajar siswa secara klasikal, yaitu minimal $70 \%$ siswa yang megikuti pembelajaran mampu mencapai minimal 75 dan (b) ketercapaian tujuan pembelajaran $75 \%$.

Hasil dari uji coba I dan II terkait ketiga aspek tersebut akan disajikan sebagai berikut :

\section{(a) Ketuntasan Klasikal}

Dalam penelitian ini, tingkat penguasaan siswa ditinjau dari kemampuan pemecahan masalah matematis siswa dengan menggunakan tes kemampuan pemecahan masalah matematis. Deskripsi hasil kemampuan pemecahan masalah matematis siswa pada uji coba I dan II sebagai berikut :

Tabel 2.

Tingkat Ketuntasan Klasikal Kemampuan Pemecahan Masalah Matematis Siswa pada Uji Coba I

\begin{tabular}{ccc}
\hline \multirow{2}{*}{ Kategori } & \multicolumn{2}{c}{ Kemampuan Pemecahan Masalah } \\
\cline { 2 - 3 } & Jumlah Siswa & Persentase \\
\hline Tuntas & 13 & $65 \%$ \\
\hline Tidak Tuntas & 7 & $35 \%$ \\
\hline Jumlah & 20 & $100 \%$ \\
\hline
\end{tabular}

Gambaran persentase kriteria ketuntasan klasikal kemampuan pemecahan masalah matematis siswa pada uji coba I disajikan dalam gambar 1 berikut. 


\section{Persentase Ketuntasan \\ Klasikal Kemampuan \\ Pemecahan Masalah Matematika pada Uji Coba 1}

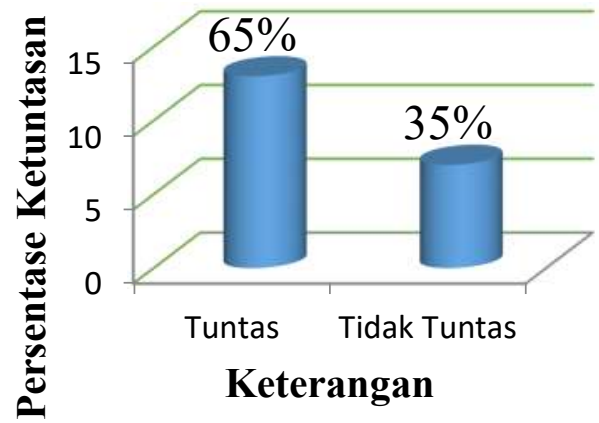

Gambar 2. Persentase Ketuntasan Klasikal Kemampuan Pemecahan Masalah Matematis pada Uji Coba I

Berdasarkan tabel 2 dan gambar 1 diatas, terlihat bahwa ketuntasan belajar siswa secara klasikal dari hasil kemampuan pemecahan masalah yaitu banyaknya siswa yang tuntas adalah 13 orang dari 20 orang siswa (65\%) dan banyaknya siswa yang tidak tuntas adalah 7 orang dari 20 orang siswa (35\%). Sesuai dengan kriteria ketuntasan belajar siswa secara klasikal, yaitu minimal $70 \%$ siswa yang mengikuti pembelajaran mampu mencapai skor $\geq 75$. Dengan demikian disimpulkan bahwa hasil post test kemampuan pemecahan masalah matematis pada uji coba I belum memenuhi kriteria pencapaian ketuntasan secara klasikal.

Selanjutnya dilakukan uji coba II. Untuk melihat ketuntasan klasikalnya, hasil yang didapat adalah sebagai berikut:

Tabel 3.

Tingkat Ketuntasan Klasikal Kemampuan Pemecahan Masalah Matematis Siswa pada Uji Coba II

\begin{tabular}{ccc}
\hline \multirow{2}{*}{ Kategori } & \multicolumn{2}{c}{ Kemampuan Pemecahan Masalah } \\
\cline { 2 - 3 } & Jumlah Siswa & Persentase \\
\hline Tuntas & 16 & $80 \%$ \\
\hline Tidak Tuntas & 4 & $20 \%$ \\
\hline Jumlah & 20 & $100 \%$ \\
\hline
\end{tabular}

Gambaran persentase kriteria ketuntasan klasikal kemampuan pemecahan masalah matematis siswa pada uji coba II disajikan dalam gambar 2 berikut. 


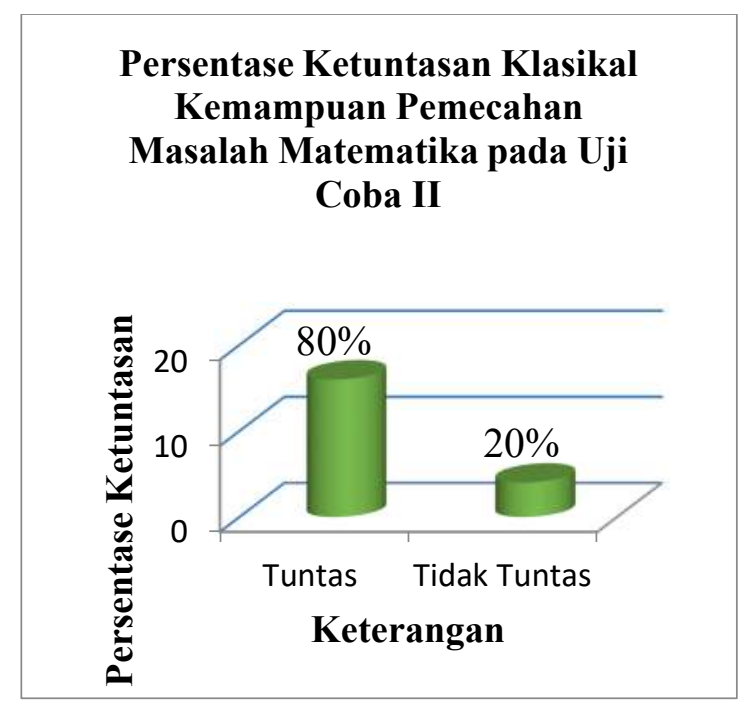

Gambar 2. Persentase Ketuntasan Klasikal Kemampuan Pemecahan Masalah Matematis pada Uji Coba II

Terlihat bahwa ketuntasan belajar siswa secara klasikal dari hasil kemampuan pemecahan masalah yaitu banyaknya siswa yang tuntas adalah 16 orang dari 20 orang siswa $(80 \%)$ dan banyaknya siswa yang tidak tuntas adalah 4 orang dari 20 orang siswa (20\%). Sesuai dengan kriteria ketuntasan belajar siswa secara klasikal, yaitu minimal 75\% siswa yang mengikuti pembelajaran mampu mencapai skor $\geq 75$. Dengan demikian disimpulkan bahwa hasil posttest kemampuan pemecahan masalah matematis pada uji coba II memenuhi kriteria pencapaian ketuntasan secara klasikal.

\section{(b) Ketercapaian Tujuan Pembelajaran}

Analisis ketercapaian tujuan pembelajaran dilakukan untuk mengetahui persentase ketercapaian tujuan pembelajaran untuk setiap butir posttest kemampuan pemecahan masalah matematis. Kriteria tujuan pembelajaran dikatakan tercapai apabila persentasenya $\geq 75 \%$. Ketercapaian tujuan pembelajaran terhadap kemampuan pemecahan masalah matematis pada uji coba I dan pada uji coba II dapat dilihat sebagai berikut:

Tercapainya tujuan pembelajaran kemampuan pemecahan masalah pada uji coba I disajikan pada gambar 3 , sebagai berikut. 


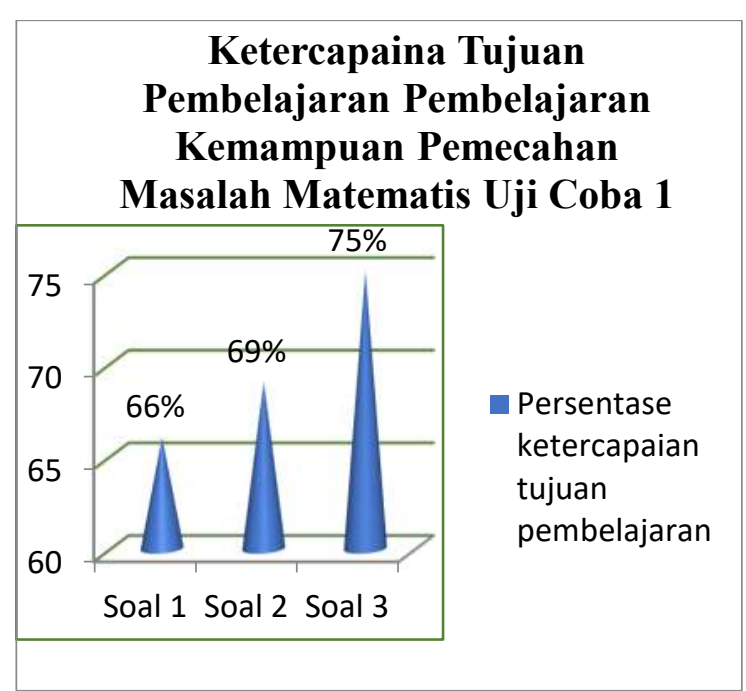

Gambar 3. Ketercapaian Tujuan Pembelajaran Terhadap Kemampuan Matematis pada Uji Coba 1

Terlihat bahwa hasil kemampuan pemecahan masalah pada uji coba I, ketercapaian tujuan pembelajaran pada soal nomor 1 diperoleh sebesar 66\%, ketercapaian tujuan pembelajaran soal nomor 2 diperoleh sebesar $69 \%$, dan ketercapaian tujuan pembelaaran soal nomor 3 diperoleh sebesar $75 \%$. Sesuai dengan kriteria tujuan pembelajaran, dikatakan tujuan pembelajaran tercapai dengan kriteria $\geq 75 \%$ dari skor maksimum tiap butir soal. Dengan demikian ketercapaian tujuan pembelajaran pada uji coba I yaitu pada hasil posttest kemampuan pemecahan masalah sudah tercapai untuk butir soal nomor 3 namun belum tercapai pada butir soal nomor 1 dan 2 .

Sedangkan ketercapaian tujuan pembelajaran kemampuan pemecahan masalah pada uji coba II dapat dilihat pada gambar 4 berikut.

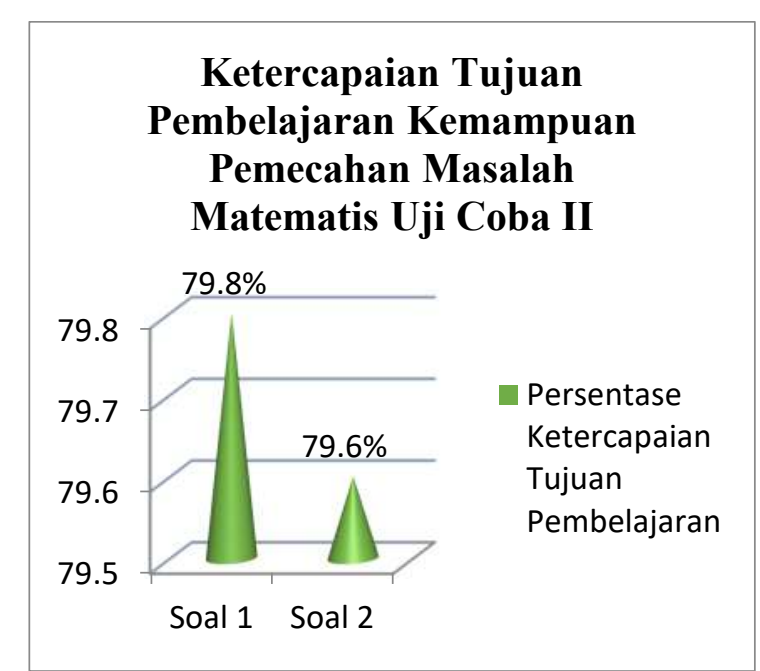

Gambar 4. Ketercapaian Tujuan Pembelajaran Terhadap Kemampuan Matematis pada Uji Coba 1I

Terlihat bahwa hasil kemampuan pemecahan masalah pada uji coba II, ketercapaian tujuan pembelajaran pada soal nomor 1 diperoleh sebesar $79,8 \%$, dan ketercapaian tujuan pembelajaran soal nomor 2 diperoleh sebesar 79,6\%. Sesuai dengan 
kriteria tujuan pembelajaran, dikatakan tujuan pembelajaran tercapai dengan kriteria $\geq$ $75 \%$ dari skor maksimum tiap butir soal. Dengan demikian ketercapaian tujuan pembelajaran pada uji coba II yaitu pada hasil posttest kemampuan pemecahan masalah sudah tercapai untuk butir soal nomor 1 dan 2 .

\section{Deskripsi Respon Siswa}

Analisis respon siswa ini dilakukan untuk melihat bagaimana respon siswa terhadap bahan ajar berbasis masalah terintegrasi etnomatematika. Angket respon siswa ini diberikan setelah kegiatan belajar selesai pada setiap uji coba.

Respon siswa terhadap pembelajaran dan bahan ajar yang digunakan di dalam pembelajaran meliputi respon positif dan dan respon negatif. Siswa dikatakan memberikan respon positif apabila ia menceklis pada pilihan sangat setuju atau setuju. Sedangkan siswa dikatakan memberikan respon negatif apabila siswa menceklis pilihan tidak setuju atau sangat tidak setuju.

Angket respon siswa diberikan pada uji coba I dan pada uji coba II. Hasil angket respon siswa pada uji coba I, dapat dilihat pada tabel 4 berikut.

Tabel 4.

Hasil Angket Respon Siswa Pada Uji Coba I

\begin{tabular}{lc}
\hline \multicolumn{1}{c}{ Kriteria Jawaban } & Persentase \\
\hline Sangat Setuju & $26,5 \%$ \\
\hline Setuju & $68 \%$ \\
\hline Tidak Setuju & $5,5 \%$ \\
\hline Sangat Tidak Setuju & $0 \%$ \\
\hline
\end{tabular}

Hasil persentase siswa yang menyatakan sangat setuju 26,5\%, siswa yang menyatakan setuju 68\%, siswa yang menyatakan tidak setuju 5,5\%, dan siswa yang menyatakan sangat tidak setuju 0 , terhadap bahan ajar yang digunakan saat pembelajaran. Dengan demikian, berdasarkan hasil angket respon siswa terhadap bahan ajar berbasis masalah terintegrasi etnomatematika dapat dikatakan mendapatkan respon yang positif sehingga dengan demikian bahan ajar ini efektif untuk digunakan. berikut.

Sedangkan hasil angket respon siswa pada uji coba II, dapat dilihat pada tabel 5

Tabel 5.

Hasil Angket Respon Siswa Pada Uji Coba II

\begin{tabular}{lc}
\hline \multicolumn{1}{c}{ Kriteria Jawaban } & Persentase \\
\hline Sangat Setuju & $27 \%$ \\
\hline Setuju & $70,5 \%$ \\
\hline Tidak Setuju & $2,5 \%$ \\
\hline $\begin{array}{l}\text { Sangat Tidak } \\
\text { Setuju }\end{array}$ & $0 \%$ \\
\hline
\end{tabular}

Hasil persentase siswa yang menyatakan sangat setuju $27 \%$, siswa yang menyatakan setuju70,5\%, siswa yang menyatakan tidak setuju 2,5\%, dan siswa yang menyatakan sangat tidak setuju 0 , terhadap bahan ajar yang digunakan saat pmbelajaran. 
Dengan demikian, berdasarkan hasil angket respon siswa terhadap bahan ajar berbasis masalah terintegrasi etnomatematika dapat dikatakan mendapatkan respon yang positif sehingga dengan demikian bahan ajar ini efektif untuk digunakan.

\section{Kesimpulan}

Berdasarkan hasil analisis dan pembahasan dalam penelitian ini, dikemukakan beberapa simpulan sebagai berikut:

1. Bahan ajar berbasis masalah terintegrasi etnomatematika dinyatakan valid pada interval skor $3 \leq \mathrm{Va}<4$, dengan skor 3,22.

2. Bahan ajar berbasis masalah terintegrasi etnomatematika dalam meningkatkan kemampuan pemecahan masalah matematis sudah efektif untuk digunakan dalam pembelajaran, yang meliputi ketuntasan belajar secara klasikal, dan ketercapaian tujuan pembelajaran.

3. Respon siswa terhadap bahan ajar dan kegiatan pembelajaran adalah positif.

\section{Daftar Pustaka}

Aristia, K., Nasryah, C. E., \& Rahman, A. A. (2020). Efektifitas Penggunaan Media Pembelajaran Celengan Gambar Untuk Meningkatkan Hasil Belajar Siswa Tema Peduli Terhadap Makhluk Hidup Kelas IV SD. Edunesia: Jurnal Ilmiah Pendidikan, $1(2), 16-25$.

Kharisma, J. Y., dan Asman, A. (2018). Pengembangan Bahan Ajar Matematika Berbasis Masalah Berorientasi pada Kemampuan Pemecahan Masalah Matematis dan Prestasi Belajar Matematika. Indonesian Journal of Mathematics Education, 1(1), 34-46.

Kurniawati, I. L., dan Amarlita, D. M. (2013, December). Pengembangan bahan ajar berbasis masalah pada mata pelajaran kimia SMA kelas $X$ dalam materi hidrokarbon. In Prosiding Seminar Nasional MIPA.

Nurhidayati, S., Tayeb, T., dan Abbas, B. (2017). Pengembangan Bahan Ajar Matematika Berbasis Masalah untuk Memfasilitasi Pencapaian Kemampuan Penalaran Pada Pokok Bahasan Perbandingan Kelas VII MTsN Model Makassar. MaPan: Jurnal Matematia dan Pembelajaran, 5(2), 236-250.

Nurliastuti, E., Dewi, N. R., dan Priyatno, S. (2018, February). Penerapan Model PBL Bernuansa Etnomatematika untuk Meningkatkan Kemampuan Pemecahan Masalah Matematis dan Motivasi Belajar Siswa. In PRISMA, Prosiding Seminar Nasional Matematika, (Vol. 1, pp. 99-104).

Permendiknas No 22. (2016). Standar Isi Untuk Satuan Pendidikan Dasar dan Menengah. Jakarta: Peraturan Menteri Pendidikan Nasional.

https://asefts63.files.wordpress.com

Rahman, A. A. (2018). Pengembangan Perangkat Pembelajaran Berbasis pendekatan Realistik untuk Meningkatkan Kemampuan Pemecahan Masalah Matematis Siswa SMP N 3 Langsa. MAJU: Jurnal Ilmiah Pendidikan Matematika, 4(1). 
Setyaningrum, B. D. N. (2018). Budaya Lokal di Era Global. Jurnal Ekspresi Seni, 2(2), 102112.

Tanjung, H. S. (2018). Perbedaan Kemampuan Berpikir Kreatif dan Pemecahan Masalah Matematis Siswa dalam Penerapan Model Pembelajaran berbasi Masalah. Genta Mulia: Jurnal Ilmiah Pendidikan, 10(1).

Ulfa, M. S., \& Nasryah, C. E. (2020). Pengembangan Media Pembelajaran Pop-Up Book Untuk Meningkatkan Motivasi Belajar Siswa Kelas IV SD. Edunesia: Jurnal Ilmiah Pendidikan, 1(1), 10-16. 